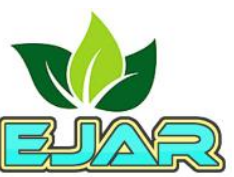

\title{
Bio Management of Crown Rot and Southern Blight of Carrot by Using Trichoderma Fortified Compost
}

\author{
Mahmudul Hasan ${ }^{1}$, Rayhanur Jannat $^{1 *}$ (D), Preangka Saha Briste ${ }^{1}$ (D), Md. Mofazzal Hossain ${ }^{2}$, and Md. Khurshed \\ Alam Bhuiyan ${ }^{1}$ \\ Address \\ ${ }^{1}$ Department of Plant Pathology, Faculty of Agriculture, Bangabandhu Sheikh Mujibur Rahman Agricultural University, Gazipur-1706, \\ Bangladesh \\ ${ }^{2}$ Department of Horticulture, Faculty of Agriculture, Bangabandhu Sheikh Mujibur Rahman Agricultural University, Gazipur-1706, \\ Bangladesh \\ * Corresponding author: Rayhanur Jannat, Email: rjannat@bsmrau.edu.bd \\ Received: 16.06.2021; Accepted: 29.08.2021; Published: 11.09.2021 \\ $\underline{10.21608 / \text { ejar.2021.78675.1113 }}$
}

\section{ABSTRACT}

Rhizoctonia crown rot and canker caused by Rhizoctonia solani and southern blight caused by Sclerotium rolfsii are the two main devastating diseases that hamper carrot production greatly in Bangladesh. Indiscriminate use of chemical fungicides in controlling the pathogens also pollutes the environment, so an alternative bio-control agent was used to control the diseases. In the pathogenicity test, R-1 isolate of $R$. solani and S-1 isolate of S. rolfsii was found to be the most virulent against carrot seedlings and harvested carrots. T. harzianum isolate $\mathrm{Pb}-7$ was appeared to be the most effective antagonist in the preliminary screening against both the selected pathogens. The field experiment was laid out following a randomized complete block design with five treatments and three replications. In pathogen inoculated fields, $200 \mathrm{~g}$ and $400 \mathrm{~g}$ wheat grain colonized Trichoderma fortified compost, composted poultry refuges were mixed in the soil as per treatment before sowing carrot seeds. Pre- and post-emergence seedling mortality, the incidence of Rhizoctonia crown rot and canker, and southern blight of carrot reduced significantly in treatments where soil was amended by wheat grain colonized Trichoderma fortified compost. On the contrary, pre-and post-emergence seedling mortality, incidence of Rhizoctonia crown rot and canker and southern blight of carrot was highest in pathogen inoculated fields. Trichoderma fortified compost enhanced germination percentage, growthpromoting factors, yield and yield contributing components. The concentration of $400 \mathrm{~g}$ wheat grain colonized Trichoderma fortified compost can be a suitable alternative to chemical fungicides used against these two devastating diseases of carrot. Keywords: Carrot, Crown rot, Southern blight, Trichoderma fortified compost

\section{INTRODUCTION}

Carrot (Daucus carota L, var. sativas Hoffm) is a root crop, cultivated worldwide as a major vegetable in cool weather which belongs to the family Apiaceae. It is considered that they originated in Asiatic region especial emphasis is given in Central Asia from where they spread worldwide. They thrive well in winter season under tropical and subtropical climates whereas, they can be grown in almost all seasons e.g. summer, autumn, and spring in temperate regions of the world. They are valued for their nutritional as well as medicinal value and especially for their carotene content, as they possess very high carotene content. They are also rich in vitamin B and C, and sugar (Uddin and Hoque, 2004). But they are subjected to a wide range of field stresses which include diseases and variation in soil condition, notably moisture. The diseases that hamper carrot production severely are bacterial soft rot, Pythium rot, southern blight, Rhizoctonia crown rot and canker, violate rot, cavity spot, cottony rot, black rot, scab, etc. Little information or sometimes no information is found about these diseases of carrot as well as their management.

The two main diseases that occur both in the field and storage condition are crown rot and canker caused by $R$. solani, southern blight caused by S. rolfsii (Grisham and Anderson, 1983; Ahmed et al., 2019). Both the diseases severely knock off carrot quality ultimately lessens carrot production. That results in a huge economic loss to the farmers. But still, limited information is found about the disease epidemiology of these two pathogens as well as their control strategy. It is a very tough job to control soil-borne diseases because here the main tool that is gone through the reclamation process is soil. That's why numerous synthetic fungicides are used extensively for controlling diseases in the shortest possible time. The indiscriminate use of these fungicides harms the environment as well as on human health. Considering the deleterious effect of synthetic pesticides, there has been arisen an urge for finding alternative and effective ways to control the diseases. The use of beneficial microorganisms in controlling devastating plant diseases has become a suitable alternative, followed by researchers around the world. They have been seeking an effective bio-control agent for decades. Numerous beneficial microbes have been isolates successfully. Among them, Trichoderma sp. has been found as a blasting mycoparasite that combat with other soil fungi aggressively and suppress their further growth (Jenkins and Averre, 1986). That's why they may play a great role as a biocontrol agent and sustainably controlling the disease.

Trichoderma strains can control numerous plant pathogens as well as promote plant health by improving soil fertility and they are now commercially available also (Samuels, 1996). These activities make Trichoderma one of the most appealing 
alternatives to chemical fungicides and fertilizers. To date, a number of Trichoderma species have been reported to be effective antagonists against Fusarium oxysporum and S. rolfsii (Begum et al., 1998). Trichoderma spp. has been found as the predominant and aggressive parasite against Rhizoctonia and Sclerotium and Trichoderma fortified compost are also effective in controlling soil-borne pathogens (Nitu et al., 2016; Kuter et al., 1983). The development of an integrated bio management technology against crown rot and canker as well as southern blight would help minimize crop losses due to these diseases. The main objectives of the current study are to screen some $T$. harzianum isolates against $R$. solani and $S$. rolfsii in-vitro and open fields.

\section{MATERIALS AND METHODS}

The experiment was set in the Plant disease diagnostic clinic, microbiology laboratory, and the farm allotted for the Department of Plant Pathology in Bangabandhu Sheikh Mujibur Rahman Agricultural University (BSMRAU), Gazipur.

\section{Collection, isolation, and preservation of Trichoderma isolates:}

About 60 soil samples were culled from the rhizosphere region of different crops including carrot, radish, tomato, potato, cabbage, cauliflower, amaranths, red amaranth, brinjal, okra, bush-bean, pea, and chilli fields of Gazipur, Mymensingh, and Pabna districts. At least 20 soil samples were collected from each district representing different crop fields and leastways three places of a specific crop field or land were mixed up for making an individual sample. Then a conical flask was taken where 90 $\mathrm{ml}$ sterilized distilled water was added in ten grams of soil which was taken from a soil sample and left with a magnetic stirrer for 20 minutes for stirring the sample. Then $10 \mathrm{ml}$ of suspension was withdrawn in a conical flask and $90 \mathrm{ml}$ of sterile water was added to make $100 \mathrm{ml}$ suspension and it was vortexed for two minutes which was repeated up to 5 -fold serial dilution was made. Then $0.5 \mathrm{ml}$ of each dilution was spread evenly using a turntable on PDA plate and incubated at room temperature $\left(25 \pm 2^{\circ} \mathrm{C}\right)$. The hyphal tip culture technique was used to purify Trichoderma spp. on PDA (Tuite, 1969). For the identification of $T$. harzianum, their growth and characteristics as well as colony appearances were taken into account. On basis of this characteristics and following standard procedure (Barnett, 1972), around 20 isolates of T. harzianum were identified.

\section{Collection, isolation and preservation of $R$. solani and S. rolfsii:}

Diseased samples showing Rhizoctonia crown rot and canker symptoms were collected from infested fields and brought to the Plant Diseased Diagnostic Clinic at BSMRAU for identification and purification. The diseased samples were washed thoroughly in running tap water for removing attached soil particles and impurities. Then from the edge of healthy and dead tissue, the specimens were cut measuring $5 \mathrm{~mm}$ in size each. Surface sterilization of those small pieces was done by treating them with $0.1 \% \mathrm{NaOCl}$ for 2 minutes which was again rinsed in sterilized water three times, then it was dried to remove excess water. They were put on acidified PDA plates and incubated for 5 days at room temperature. After incubation, they were purified by the hyphal tip culture method. The pure culture of $R$. solani was preserved by using PDA slants at $10^{\circ} \mathrm{C}$ as the stock culture for future use.

S. rolfsii was isolated from the naturally infected carrot, lentil, pea, potato and bush bean grown in the field of Gazipur district. Isolation was done following tissue planting method as stated above. For purification, single sclerotia from each colony were grown on PDA by following the standard method (Ganesan et al., 1987).

\section{Inoculum preparation of test pathogens:}

Wheat grain was used for the preparation of inocula by following the standard procedure (Sivan et al., 1984). In field experiments, $40 \mathrm{~g}$ wheat grain colonized inoculum was applied per plot as per the required treatments before sowing the seeds.

Pathogenicity test for the selection of virulent isolates of the test pathogens in pot culture:

For the pathogenicity test, a shady area in front of the plant pathology laboratory was chosen and pots were used for completion of the test. Isolate R-1, R-2, and R-3 of R. solani and S-1, S-2 and S-3 of S. rolfsii were tested for their virulence against pre-emergence and post-emergence seedling mortality of carrot following the methods as stated by Grisham and Anderson, (1983). Two experiments, one for $R$. solani and another for S. rolfsii were conducted.

\section{Preparation of pot soil and sowing of seed in the earthen pot:}

Around $1 \mathrm{~kg}$ Steamed sterilized soil mixture (clay loam + river sand along with cow dung) was poured into each earthen pot (15 $\mathrm{cm}$ diameter and $15 \mathrm{~cm}$ height). With a $1 \mathrm{~kg}$ soil mixture, $20 \mathrm{~g}$ inoculum of each isolates was mixed with and incubated for five days. Pot with sterilized soil not infected with pathogen served as control. One hundred carrot seeds (variety -New Kuroda) were sown in each pot (Grisham and Anderson, 1983). Three replications for each treatment (isolates and control) were maintained and arranged following Completely Randomized Design (CRD) on the floor. For the estimation of the effect of the pathogen causing pre-emergence and post-emergence seedling mortality, they were observed regularly after 10, 20, and 30 days of sowing. Three carrots for each replication and three replications for each isolate (treatment) were observed for DI (disease Incidence) and PDI (Percent Disease Index). After sixty days, disease severity was rated following scale 0-5, where $0=$ no symptoms of disease, 1 = less than $15 \%, 2=15-35 \%, 3=36-49 \%, 4=50-75 \% 5=$ more than $75 \%$ lesion or mycelium on harvested mature carrot.

Disease incidence and percent disease index (PDI) were assessed by using the following formula:

Disease incidence $(\%)=\frac{\text { Number of infected plants }}{\text { Total number of plants observed }} \times 100$

PDI $=\frac{\Sigma \text { of rating of plants observed }}{\text { Number of plants observed } \times \text { Highest score of the scale used }} \times 100$ 
Per cent disease control (PDC) was calculated by the following formula:

PDC $=\frac{(\% \text { disease in check })-(\% \text { disease in treatment })}{(\% \text { disease in check })} \times 100$

\section{In vitro screening of Trichoderma isolates:}

For the evaluation of the antagonistic effect, all the 7 isolates of $T$. harzianum were screened in-vitro against $R$. solani and $S$. rolfsii on PDA. The dual plate Culture technique was used for screening (Dhingra and Sinclair, 1985). Inhibition percentages of the two pathogens were calculated on their growth on PDA plate after incubation them for 3-5 days following the formula as suggested by Ramesh Sundar et al., (1995).

$\%$ Inhibition of growth $=\frac{X-Y}{X} \times 100$

Where,

$\mathrm{X}=$ Mycelial growth of pathogen in absence of Trichoderma (control),

$\mathrm{Y}=$ Mycelial growth of pathogen in presence of Trichoderma.

The antagonism potentiality of the isolates of Trichoderma was evaluated by following the standard indexing scale of 1-5 as suggested by Bell et al., (1982), where

$R_{1}=100 \%$ overgrowth, $R_{2}=75 \%$ overgrowth, $R_{3}=55 \%$ overgrowth,

$\mathrm{R}_{4}=$ block at the point of contact, $\mathrm{R}_{5}=$ pathogen overgrowth antagonistic.

Preparation of wheat grain colonized T. harzianum:

On wheat grains, the inoculum of the isolates of $T$. harzianum was prepared in a $500 \mathrm{ml}$ Erlenmeyer flask by following standard procedure (Sivan et al., 1984).

Preparation of $T$. harzianum fortified compost with poultry refuges:

$T$. harzianum fortified compost with poultry refuges was prepared by following the procedure as described by (James, 2008). Before sowing seeds, $200 \mathrm{~g}$ and $400 \mathrm{~g} T$. harzianum fortified compost were amended per plots as per the required treatments. One compost pit without wheat grain colonized $T$. harzianum inoculum was maintained as a control treatment.

\section{Land preparation and design of experiment:}

For the preparation of land a disc plough, and harrow were used, and they were driven in the field using a tractor. Randomized Complete Block Design (RCBD) with three replications was used for designing the experiment. For ensuring three replications the whole area which was prepared were divided into three blocks, and each block represented a replication. The size of each plot was maintained at about $2.0 \mathrm{~m} \times 2.0 \mathrm{~m}$. About $1 \mathrm{~m}$ distance from one block to another and $0.50 \mathrm{~m}$ distance from one plot to another of a block was maintained. Randomly five plots per block were chosen for the allocation of the 5 treatments.

\section{Treatments:}

Following treatments were applied in the field experiment:

$\mathrm{T}_{1}=$ without any treatments (only fertilizers)

$\mathrm{T}_{2}=$ Soil inoculated with pathogen

$\mathrm{T}_{3}=$ Soil inoculated with pathogen $+200 \mathrm{~g}$ wheat grain colonized Trichoderma fortified compost

$\mathrm{T}_{4}=$ Soil inoculated with pathogen $+400 \mathrm{~g}$ wheat grain colonized Trichoderma fortified compost, and

$\mathrm{T}_{5}=$ Soil inoculated with pathogen + compost

\section{Use of manure and fertilizer:}

Around 5-ton cow dung was applied per hectare of land while preparation of the soil. Alongside cow dung, about $200 \mathrm{~kg}$ urea, $100 \mathrm{~kg}$ of Triple Super Phosphate (TSP), and $175 \mathrm{~kg}$ of Muriate of Potash (MP) were applied per hectare of land. During final land preparation, the whole $100 \mathrm{~kg}$ of TSP, one-third portion of the MoP, and one-third proportion of Urea were applied in the soil. And the remaining proportion of Urea and MoP was applied as a top dressing after 30 and 50 days of sowing followed by irrigation.

\section{Statistical analysis:}

The data of various parameters recorded in this study were analyzed using Statistix 10 software of statistical computer program after transformation whenever necessary. The means were compared following the LSD (Least Significant Difference) test at a $5 \%$ significance level.

\section{RESULTS}

Pathogenicity test of $\boldsymbol{R}$. solani and $\boldsymbol{S}$. rolfsii isolates on carrot seedlings in pot culture:

The results of pathogenicity test show that the isolate $\mathrm{R}-1$ of $R$. solani gave highest seedling mortality percentage and the total mortality percentage was $91.07 \%$. On the other hand, the isolate S-1 of S. rolfsii showed highest pre-emergence and postemergence seedling mortality. The total mortality percentage found here were $92.33 \%$. The results are represented in Table 1, and Fig 1 . As the R-1 and S-1 isolate showed the highest mortality percentage, they were regarded as the most virulent ones. 
Table 1. Pathogenicity test of S. rolfsii and R. solani isolates against carrot seedlings grown in pot

\begin{tabular}{|c|c|c|c|}
\hline Isolates & Pre-emergence mortality (\%) & Post-emergence mortality (\%) & Total mortality (\%) \\
\hline \multicolumn{3}{|c|}{ R. solani } \\
\hline R-1 & 55.77 & 35.30 & $91.07 \mathrm{a}$ \\
\hline R-2 & 44.83 & 30.17 & $70.00 \mathrm{~b}$ \\
\hline R-3 & 35.33 & 23.78 & $59.11 \mathrm{c}$ \\
\hline Control & 0 & 0 & 0 \\
\hline \multicolumn{5}{|c|}{ S. rolfsii } \\
\hline S-1 & 67.17 & 25.17 & $92.33 \mathrm{a}$ \\
\hline S-2 & 55.00 & 14.87 & $59.87 \mathrm{~b}$ \\
\hline Control & 35.00 & 22.33 & 0 \\
\hline
\end{tabular}

* Mean values within the column having the same letter do not differ significantly.

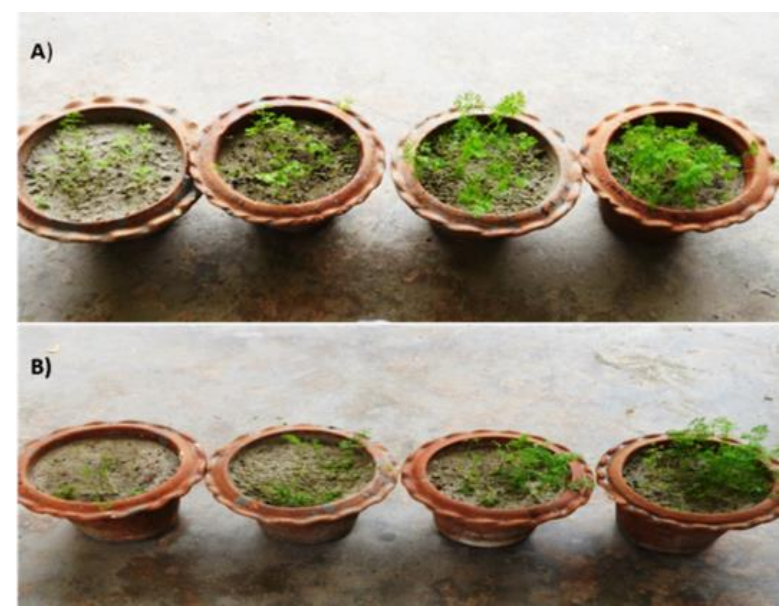

Fig. 1: Pathogenicity test of A) R. solani (R-1, R-2, R-3) isolate and control from left and B) S. rolfsii (S-1, S-2, S-3) isolate and control from left on carrot seedlings grown in pot.

Pathogenicity of $\boldsymbol{R}$. solani and S. rolfsii isolates on harvested carrot in pot culture:

The 3 isolates of $R$. solani and S. rolfsii used in this study were found pathogenic and caused disease on carrot (Table 2 ). In $R$. solani inoculated pots brown to the black sunken cankerous lesion was found on carrot root (Fig. 2). While the pots inoculated with S. rolfsii, showed soft watery decay of the taproot near or at the soil line was observed. The leaves of the carrot plant wilted and as the disease progressed, mats of white mycelia were found in root as well as in the soil region surrounding the carrot. Small resting structures (sclerotia) developed on the mats of mycelium, which proved the presence of $S$. rolfsii. As we found that, the R-1 and S-1 isolates causing significantly higher DI as well as PDI to carrot, they were used for the further field experiments.

Table 2. Pathogenicity test of $R$. solani and S. rolfsii isolates on harvested carrot

\begin{tabular}{|c|c|c|}
\hline & Disease Incidence (\%) & Percent Disease Index \\
\hline Isolates & \multicolumn{1}{|c|}{ R. solani } \\
\hline \multicolumn{3}{|c|}{$46.77 \mathrm{a}$} \\
\hline $\mathrm{R}-1$ & $58.11 \mathrm{a}$ & $30.70 \mathrm{~b}$ \\
\hline $\mathrm{R}-2$ & $40.03 \mathrm{~b}$ & $20.48 \mathrm{c}$ \\
\hline R-3 & $28.99 \mathrm{c}$ & $0.00 \mathrm{~d}$ \\
\hline Control & $0.00 \mathrm{~d}$ & $57.09 \mathrm{a}$ \\
\hline \multicolumn{3}{|c|}{ S. rolfsii } \\
\hline S-1 & $76.24 \mathrm{a}$ & $30.90 \mathrm{~b}$ \\
\hline S-2 & $63.33 \mathrm{~b}$ & $17.30 \mathrm{c}$ \\
\hline S-3 & $44.11 \mathrm{c}$ & $0.00 \mathrm{~d}$ \\
\hline
\end{tabular}

* Mean values within the column having the same letter do not differ significantly. 

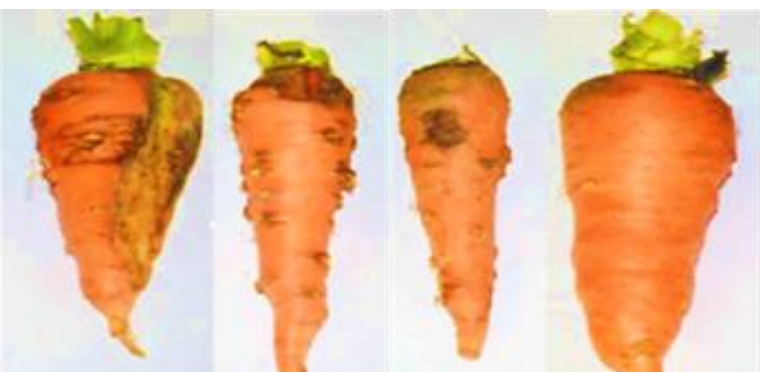

A) R-1

B) $\mathbf{R - 2}$

C) R-3

D)Control

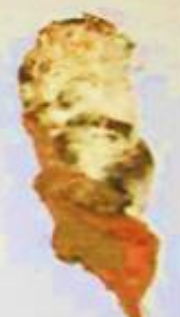

E) S-1

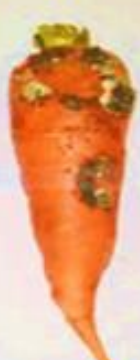

F) S-2

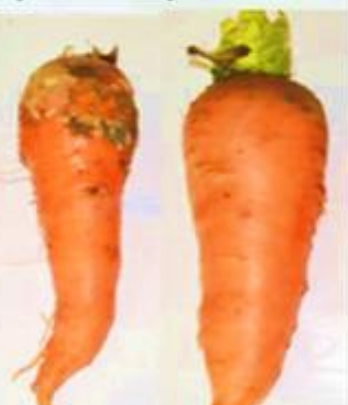

G) S-3 H) Control

Fig 2. Pathogenicity test of $R$. solani isolates (A-D) and S. rolfsii isolates (E-H) on harvested carrot in pot culture.

In vitro screening of $T$. harzianum isolates against virulent isolates of $R$. solani and S. rolfsii:

All the isolates of $T$. harzianum used in this study showed $50 \%$ or more than $50 \%$ radial growth inhibition of the tested isolates of $R$. solani and S. rolfsii, respectively over control (Table 3) and (Fig. 3). Among all the isolates tested the Pb-7 isolate of $T$. harzianum showed the highest antagonistic effect against the test pathogens. As the $\mathrm{Pb}-7$ isolate have the highest antagonistic capability, it was selected for the preparation of Trichoderma fortified compost and for further usage the isolate were preserved in PDA slant at $10^{\circ} \mathrm{C}$.

Table 3. Screening of $T$. harzianum isolates against $R$. solani and $S$. rolfsii in Dual Culture Technique

\begin{tabular}{|c|c|c|c|}
\hline $\begin{array}{c}\text { T. harzianum } \\
\text { Isolates }\end{array}$ & $\begin{array}{c}\text { Average mycelial growth of } \boldsymbol{R} . \\
\text { solani (mm) }\end{array}$ & $\begin{array}{c}\text { \% inhibition over } \\
\text { control }\end{array}$ & $\begin{array}{c}\text { Alignment of Trichoderma in } \\
\text { Bell's scale* }\end{array}$ \\
\hline Pb-7 & $7.00 \mathrm{~g}$ & 91.25 & $\mathrm{R}_{1}$ \\
\hline Pb-10 solani & $\mathrm{R}_{1}$ \\
\hline Pb-13 & $14.21 \mathrm{ef}$ & 82.23 & $\mathrm{R}_{1}$ \\
\hline BSMRAU-1 & $15.00 \mathrm{e}$ & 81.25 & $\mathrm{R}_{1}$ \\
\hline BSMRAU-2 & $18.00 \mathrm{~d}$ & 77.50 & $\mathrm{R}_{2}$ \\
\hline Rajendepur & $25.00 \mathrm{c}$ & 68.75 & $\mathrm{R}_{2}$ \\
\hline MYT-75 & $30.12 \mathrm{~b}$ & 62.35 & $\mathrm{R}_{1}$ \\
\hline Control & $13.00 \mathrm{f}$ & 83.75 & - \\
\hline Pb-7 & $80.00 \mathrm{a}$ & 0.00 & $\mathrm{R}_{1}$ \\
\hline Pb-10 & $10.67 \mathrm{~g}$ & 86.67 & $\mathrm{R}_{1}$ \\
\hline Pb-13 & $19.34 \mathrm{f}$ & 75.83 & $\mathrm{R}_{2}$ \\
\hline BSMRAU-1 rolfsii & 69.63 & $\mathrm{R}_{2}$ \\
\hline BSMRAU-2 & $24.30 \mathrm{e}$ & 62.50 & $\mathrm{R}_{2}$ \\
\hline Rajendepur & $30.00 \mathrm{~d}$ & 56.67 & $\mathrm{R}_{3}$ \\
\hline MYT-75 & $34.67 \mathrm{c}$ & 50.00 & $\mathrm{R}_{1}$ \\
\hline Control & $40.00 \mathrm{~b}$ & 75.86 & - \\
\hline
\end{tabular}

* Mean values within the column having the same letter do not differ significantly. Note: $R_{1}=\geq 75 \%$ overgrowth of Trichoderma, $R_{2}=\geq 60 \%$ overgrowth of Trichoderma, $\mathrm{R}_{3}=250 \%$ overgrowth of Trichoderma, $\mathrm{R}_{4}=$ Block at the point of contact and $\mathrm{R}_{5}=$ Pathogen overgrows against antagonist. 


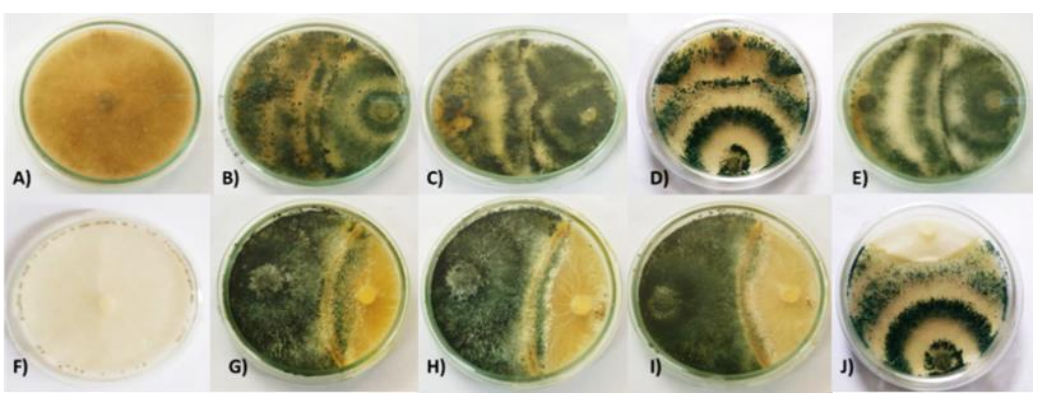

Fig 3. Antagonistic effect of $\mathrm{Pb}-7, \mathrm{~Pb}-10, \mathrm{MYT}-75$ and BSMRAU-1 of $T$. harzianum respectively, against virulent isolates of $R$. solani (B-E) and of S. rolfsii (G-J) where (A \& F) are control.

Effect of $T$. harzianum fortified compost on germination and seedling mortality of carrot caused by $R$. solani and $S$. rolfsii: All the treatments of Trichoderma increased the germination percentage and decreased pre-emergence and post-emergence seedling mortality than treatment $\mathrm{T}_{2}$ (pathogen inoculated soil). The results are presented in (Table 4). Significantly highest germination percentage $(90.73 \%$ and $91.15 \%)$ and lowest pre-emergence $(9.26 \%$ and $8.84 \%)$, post-emergence $(7.80 \%$ and 8.23\%) seedling mortality were observed in $\mathrm{T}_{4}$ treatment where $400 \mathrm{gm}$ wheat grain colonized Trichoderma fortified compost was applied in $R$. solani and $S$. rolfsii inoculated fields, respectively.

Table 4. Effect of different treatments of $T$. harzianum on germination and seedling mortality of carrot caused by $R$. solani and S. rolfsii

\begin{tabular}{|c|c|c|c|}
\hline Treatment & Germination (\%) & Pre-emergence mortality (\%) & Post-emergence mortality (\%) \\
\hline \multicolumn{4}{|c|}{ R. solani } \\
\hline $\mathrm{T}_{1}$ & $67.49 \mathrm{~d}$ & $31.94 \mathrm{~b}$ & $13.46 \mathrm{c}$ \\
\hline $\mathrm{T}_{2}$ & $52.27 \mathrm{e}$ & $42.72 \mathrm{a}$ & $30.39 \mathrm{a}$ \\
\hline $\mathrm{T}_{3}$ & $81.82 \mathrm{~b}$ & $18.17 \mathrm{c}$ & $9.96 \mathrm{~d}$ \\
\hline $\mathrm{T}_{4}$ & $90.73 \mathrm{a}$ & $9.26 \mathrm{~d}$ & $7.80 \mathrm{e}$ \\
\hline$T_{5}$ & $74.50 \mathrm{c}$ & $25.63 \mathrm{~b}$ & $18.17 \mathrm{~b}$ \\
\hline \multicolumn{4}{|c|}{ S. rolfsii } \\
\hline $\mathrm{T}_{1}$ & $67.16 \mathrm{~d}$ & $32.66 \mathrm{~b}$ & $15.13 \mathrm{bc}$ \\
\hline $\mathrm{T}_{2}$ & $49.33 \mathrm{e}$ & $51.66 \mathrm{a}$ & $37.03 \mathrm{a}$ \\
\hline $\mathrm{T}_{3}$ & $81.10 \mathrm{~b}$ & $18.90 \mathrm{~d}$ & $12.03 \mathrm{c}$ \\
\hline $\mathrm{T}_{4}$ & $91.15 \mathrm{a}$ & $8.84 \mathrm{e}$ & $8.23 \mathrm{~d}$ \\
\hline $\mathrm{T}_{5}$ & $73.94 \mathrm{c}$ & $26.06 \mathrm{~d}$ & $17.26 \mathrm{~b}$ \\
\hline
\end{tabular}

* Mean values within the column having the same letter do not differ significantly. Note: $\mathrm{T}_{1}=$ control (without any treatment, only fertilizers), $\mathrm{T}_{2}=$ Soil inoculated with the pathogen, $\mathrm{T}_{3}=$ Soil inoculated with the pathogen $+200 \mathrm{~g}$ wheat grain colonized Trichoderma fortified compost, $\mathrm{T}_{4}=$ Soil inoculated with pathogen $+400 \mathrm{~g}$ wheat grain colonized Trichoderma fortified compost and $\mathrm{T}_{5}=$ Soil inoculated with pathogen + compost.

Effect of $T$. harzianum fortified compost on growth parameters of carrot seedlings at different days after sowing (DAS) in $R$. solani and $S$. rolfsii inoculated field:

The growth enhancement of the seedlings was found at 20,40, and 60 DAS by the application of Trichoderma fortified compost. The results are presented in Table 5. The growth promoting parameters increased, where the soil was amended with Trichoderma fortified compost compare to the treatment $\mathrm{T}_{2}$ where there was pathogen inoculated soil. In $R$. solani inoculated field the highest root length $(5.80 \mathrm{~cm}, 12.10 \mathrm{~cm}$, and $13.56 \mathrm{~cm})$, shoot length $(6.49 \mathrm{~cm}, 21.87 \mathrm{~cm}$, and $35.28 \mathrm{~cm})$, fresh weight ( $0.26 \mathrm{gm}, 3.76 \mathrm{gm}$, and $13.52 \mathrm{gm})$ and dry weight $\left(0.06 \mathrm{gm}, 0.41 \mathrm{gm}\right.$, and $1.48 \mathrm{gm}$ ) were recorded in $\mathrm{T}_{4}$ treatment at 20, 40 and 60 DAS, respectively. In the field, which was inoculated with S. rolfsii, the highest root length $(5.62 \mathrm{~cm}, 10.73 \mathrm{~cm}$ and 13.98 $\mathrm{cm})$, shoot length $(6.07 \mathrm{~cm}, 19.93 \mathrm{~cm}$ and $35.78 \mathrm{~cm})$, fresh weight $(0.27 \mathrm{gm}, 3.39 \mathrm{gm}$, and $12.04 \mathrm{gm})$ and dry weight $(0.06 \mathrm{gm}$, $0.33 \mathrm{gm}$, and $1.45 \mathrm{gm}$ ) were recorded in $\mathrm{T}_{4}$ treatment at 20, 40, and $60 \mathrm{DAS}$, respectively.

Table 5. Effect of $T$. harzianum on growth parameters of carrot at 20,40 and 60 DAS in $R$. solani and S. rolfsii inoculated field

\begin{tabular}{|c|c|c|c|c|c|c|c|c|c|c|c|c|}
\hline \multirow[t]{2}{*}{ Treatment } & \multicolumn{3}{|c|}{ Root length $(\mathrm{cm})$} & \multicolumn{3}{|c|}{ Shoot length $(\mathrm{cm})$} & \multicolumn{3}{|c|}{ Plant fresh weight (g) } & \multicolumn{3}{|c|}{ Dry weight (g) } \\
\hline & 20 DAS & 40 DAS & 60 DAS & 20 DAS & 40 DAS & 60 DAS & 20 DAS & 40 DAS & 60 DAS & 20 DAS & 40 DAS & 60 DAS \\
\hline \multicolumn{13}{|c|}{ R. solani } \\
\hline $\mathrm{T}_{1}$ & $4.61 \mathrm{~b}$ & $8.60 \mathrm{c}$ & $11.12 b$ & $5.18 \mathrm{c}$ & $16.17 \mathrm{~b}$ & $24.42 d$ & $0.15 \mathrm{c}$ & $2.40 \mathrm{c}$ & $6.64 c$ & $0.03 \mathrm{c}$ & $0.24 \mathrm{~d}$ & $0.73 \mathrm{~b}$ \\
\hline $\mathrm{T}_{2}$ & $3.91 \mathrm{c}$ & $7.58 \mathrm{~d}$ & $8.44 \mathrm{c}$ & $4.43 \mathrm{~d}$ & $14.42 \mathrm{c}$ & $21.50 \mathrm{e}$ & $0.11 \mathrm{~d}$ & $1.68 \mathrm{~d}$ & $4.02 \mathrm{~d}$ & $0.02 \mathrm{~d}$ & $0.19 \mathrm{e}$ & $0.44 \mathrm{c}$ \\
\hline $\mathrm{T}_{3}$ & $5.43 \mathrm{a}$ & $10.27 \mathrm{~b}$ & $13.08 \mathrm{a}$ & $5.82 \mathrm{~b}$ & $20.27 \mathrm{a}$ & $31.48 \mathrm{~b}$ & $0.20 \mathrm{~b}$ & $3.05 \mathrm{~b}$ & $10.76 \mathrm{~b}$ & $0.05 \mathrm{~b}$ & $0.36 \mathrm{~b}$ & $1.29 \mathrm{a}$ \\
\hline $\mathrm{T}_{4}$ & $5.80 \mathrm{a}$ & $12.10 \mathrm{a}$ & $13.56 \mathrm{a}$ & $6.49 a$ & $21.87 \mathrm{a}$ & $35.28 \mathrm{a}$ & $0.26 \mathrm{a}$ & $3.76 \mathrm{a}$ & $13.52 \mathrm{a}$ & $0.06 a$ & $0.41 \mathrm{a}$ & $1.48 \mathrm{a}$ \\
\hline$T_{5}$ & $4.79 \mathrm{~b}$ & $9.07 \mathrm{c}$ & $11.46 \mathrm{~b}$ & $5.39 \mathrm{c}$ & $17.33 \mathrm{~b}$ & $26.58 \mathrm{c}$ & $0.17 \mathrm{c}$ & $2.50 \mathrm{c}$ & $7.00 \mathrm{c}$ & $0.03 c$ & $0.28 \mathrm{c}$ & $0.82 \mathrm{~b}$ \\
\hline \multicolumn{13}{|c|}{ S. rolfsii } \\
\hline $\mathrm{T}_{1}$ & $4.69 \mathrm{~b}$ & $7.76 \mathrm{c}$ & $11.40 \mathrm{c}$ & $4.56 \mathrm{~b}$ & $16.92 \mathrm{~b}$ & $23.50 c$ & $0.16 \mathrm{~d}$ & $1.95 \mathrm{~d}$ & $6.68 c$ & $0.03 \mathrm{~b}$ & $0.19 \mathrm{~d}$ & $0.76 \mathrm{c}$ \\
\hline $\mathrm{T}_{2}$ & $4.08 \mathrm{c}$ & $6.62 \mathrm{~d}$ & $8.30 \mathrm{~d}$ & $3.93 c$ & $15.67 \mathrm{c}$ & $20.22 d$ & $0.10 \mathrm{e}$ & $1.59 \mathrm{e}$ & $3.85 \mathrm{~d}$ & $0.02 \mathrm{c}$ & $0.15 \mathrm{e}$ & $0.41 \mathrm{e}$ \\
\hline$T_{3}$ & $5.38 \mathrm{a}$ & $9.19 \mathrm{~b}$ & $12.96 \mathrm{~b}$ & $5.60 \mathrm{a}$ & $19.17 \mathrm{a}$ & $29.90 b$ & $0.23 \mathrm{~b}$ & $3.00 \mathrm{~b}$ & $9.88 \mathrm{~b}$ & $0.05 a$ & $0.29 \mathrm{~b}$ & $1.18 \mathrm{~b}$ \\
\hline $\mathrm{T}_{4}$ & $5.62 \mathrm{a}$ & $10.73 \mathrm{a}$ & $13.98 \mathrm{a}$ & $6.07 \mathrm{a}$ & $19.93 \mathrm{a}$ & $35.78 a$ & $0.27 \mathrm{a}$ & $3.39 \mathrm{a}$ & $12.04 \mathrm{a}$ & $0.06 a$ & $0.33 a$ & $1.45 \mathrm{a}$ \\
\hline$T_{5}$ & $4.69 \mathrm{~b}$ & $8.10 \mathrm{c}$ & $11.24 \mathrm{c}$ & $4.89 \mathrm{~b}$ & $16.94 \mathrm{~b}$ & $24.98 c$ & $0.19 \mathrm{c}$ & $2.26 \mathrm{c}$ & $6.76 \mathrm{c}$ & $0.03 \mathrm{~b}$ & $0.24 \mathrm{c}$ & $0.62 \mathrm{~d}$ \\
\hline
\end{tabular}


* Mean values within the column having the same letter do not differ significantly. Note: $\mathrm{T}_{1}=$ control (without any treatment, only fertilizers), $\mathrm{T}_{2}=$ Soil inoculated with the pathogen, $\mathrm{T}_{3}=$ Soil inoculated with the pathogen $+200 \mathrm{~g}$ wheat grain colonized Trichoderma fortified compost, $\mathrm{T}_{4}=$ Soil inoculated with the pathogen $+400 \mathrm{~g}$ wheat grain colonized Trichoderma fortified compost and $T_{5}=$ Soil inoculated with the pathogen + compost.

Effect of $T$. harzianum fortified compost on disease incidence (DI) and severity of Rhizoctonia crown rot and canker, and southern blight diseases of carrot:

Disease incidence and severity (PDI) were reduced in the treatments where Trichoderma was used as a biological control agent over pathogen treated plots. The results are presented in Table 6. In both the cases, significantly higher disease incidence and severity were found in treatment $T_{2}$ and a significantly higher reduction in disease incidence and severity was found in $T_{4}$ treatment over $\mathrm{T}_{2}$ treatment by using Trichoderma fortified compost.

Table 6. Effect of Trichoderma on disease incidence and severity of Rhizoctonia canker and crown rot, and southern blight diseases of carrot

\begin{tabular}{|c|c|c|c|c|}
\hline Treatment & \% DI & \% reduction over $\mathbf{T}_{\mathbf{2}}$ & \% PDI & \% reduction over $\mathbf{T}_{\mathbf{2}}$ \\
\hline \multicolumn{5}{|c|}{ R. solani } \\
\hline $\mathrm{T}_{1}$ & $15.31 \mathrm{~d}$ & 70.78 & $12.57 \mathrm{~d}$ & 64.62 \\
\hline $\mathrm{T}_{2}$ & $52.33 \mathrm{a}$ & - & $35.53 \mathrm{a}$ & - \\
\hline $\mathrm{T}_{3}$ & $21.20 \mathrm{c}$ & 59.46 & $16.44 \mathrm{c}$ & 53.72 \\
\hline $\mathrm{T}_{4}$ & $10.18 \mathrm{e}$ & 80.55 & $8.86 \mathrm{e}$ & 75.06 \\
\hline $\mathrm{T}_{5}$ & $37.27 \mathrm{~b}$ & 28.78 & $29.43 \mathrm{~b}$ & 17.16 \\
\hline \multicolumn{5}{|c|}{ S. rolfsii } \\
\hline $\mathrm{T}_{1}$ & $16.38 \mathrm{~d}$ & 69.81 & $13.57 \mathrm{~d}$ & 65.01 \\
\hline $\mathrm{T}_{2}$ & $54.27 \mathrm{a}$ & - & $38.79 \mathrm{a}$ & - \\
\hline $\mathrm{T}_{3}$ & $23.86 \mathrm{c}$ & 56.03 & $17.82 \mathrm{c}$ & 54.06 \\
\hline $\mathrm{T}_{4}$ & $11.51 \mathrm{e}$ & 78.79 & $9.10 \mathrm{e}$ & 76.55 \\
\hline $\mathrm{T}_{5}$ & $39.00 \mathrm{~b}$ & 28.14 & $31.78 \mathrm{~b}$ & 18.08 \\
\hline
\end{tabular}

* Mean values within the column having the same letter do not differ significantly. Note: T1= control (without any treatment, only fertilizers), $\mathrm{T}_{2}=$ Soil inoculated with the pathogen, $\mathrm{T}_{3}=$ Soil inoculated with the pathogen $+200 \mathrm{~g}$ wheat grain colonized Trichoderma fortified compost, $\mathrm{T}_{4}=$ Soil inoculated with the pathogen $+400 \mathrm{~g}$ wheat grain colonized Trichoderma fortified compost and $\mathrm{T}_{5}=$ Soil inoculated with pathogen + compost.

Effect of Trichoderma fortified compost on the yield and yield contributing components of carrot in Rhizoctonia crown rot and canker and Southern blight infected field:

Results of the present study indicated that, for the dispensation of Trichoderma fortified compost, yield and the components which contributed to the yield directly or indirectly were enhanced significantly in all the treatments over $\mathrm{T}_{2}$. In both the cases, treatment $\mathrm{T}_{4}$ gave significantly higher enhancement in yield, length, and diameter of carrot. The results are presented in Table 7.

Table 7. Effect of Trichoderma on the yield contributing characters and yield of carrot

\begin{tabular}{|c|c|c|c|c|c|c|}
\hline $\begin{array}{c}\text { Treatmen } \\
\mathrm{t}\end{array}$ & Length $(\mathrm{cm})$ & $\begin{array}{c}\text { \% increase over } \\
\mathrm{T}_{2}\end{array}$ & Diameter $(\mathrm{cm})$ & $\begin{array}{c}\% \text { increase over } \\
\mathrm{T}_{2}\end{array}$ & Yield (ton/ha) & $\begin{array}{c}\% \text { increase } \\
\text { over } \mathrm{T}_{2}\end{array}$ \\
\hline \multicolumn{7}{|c|}{ R. solani } \\
\hline $\mathrm{T}_{1}$ & $15.29 \mathrm{~b}$ & 15.83 & $10.20 \mathrm{c}$ & 9.15 & $21.56 \mathrm{c}$ & 79.82 \\
\hline$T_{2}$ & $13.20 \mathrm{c}$ & - & $9.35 d$ & - & $11.99 \mathrm{e}$ & - \\
\hline$T_{3}$ & $16.67 \mathrm{a}$ & 26.26 & $13.49 \mathrm{a}$ & 44.43 & $26.53 \mathrm{~b}$ & 121.23 \\
\hline $\mathrm{T}_{4}$ & $17.42 \mathrm{a}$ & 31.40 & $14.19 \mathrm{a}$ & 51.85 & $29.86 a$ & 149.03 \\
\hline$T_{5}$ & $15.40 \mathrm{~b}$ & 16.67 & $11.45 \mathrm{~b}$ & 22.60 & $20.60 \mathrm{~d}$ & 71.76 \\
\hline \multicolumn{7}{|c|}{ S. rolfsii } \\
\hline $\mathrm{T}_{1}$ & $15.29 \mathrm{~b}$ & 13.48 & $9.98 \mathrm{~d}$ & 16.89 & $22.32 c$ & 87.66 \\
\hline$T_{2}$ & $13.47 \mathrm{c}$ & - & $8.54 \mathrm{e}$ & - & $11.89 \mathrm{e}$ & - \\
\hline $\mathrm{T}_{3}$ & $16.61 \mathrm{a}$ & 23.23 & $13.26 \mathrm{~b}$ & 55.30 & $25.12 b$ & 111.21 \\
\hline $\mathrm{T}_{4}$ & $17.42 \mathrm{a}$ & 29.27 & $14.19 \mathrm{a}$ & 66.15 & $29.43 \mathrm{a}$ & 147.41 \\
\hline$T_{5}$ & $14.31 \mathrm{~cd}$ & 6.23 & $11.03 \mathrm{c}$ & 29.15 & $19.43 d$ & 63.39 \\
\hline
\end{tabular}

* Mean values within the column having the same letter do not differ significantly. Note: $T_{1}=$ control (without any treatment, only fertilizers), $T_{2}=$ Soil inoculated with the pathogen, $T_{3}=$ Soil inoculated with the pathogen $+200 \mathrm{~g}$ wheat grain colonized Trichoderma fortified compost, $\mathrm{T}_{4}=$ Soil inoculated with the pathogen $+400 \mathrm{~g}$ wheat grain colonized Trichoderma fortified compost and $\mathrm{T}_{5}=$ Soil inoculated with the pathogen + compost.

\section{DISCUSSION}

The main factor limiting the yield and commercial value of carrot production is their susceptibility to diseases. It has been found in several reports that, there are numerous pathogens which cause a number of destructive diseases in carrot. Among them, Crown rot and canker caused by $R$. solani and Southern blight caused by $S$. rolfsii are the common diseases of carrot that occur in Bangladesh. They also cause seedling mortality alongside their crown rot and southern blight symptoms which ultimately hampers the total production. In our study also it was found that the R-1 isolate of $R$. solani caused $55.77 \%$ pre-emergence 
seedling mortality and $35.30 \%$ post-emergence seedling mortality which in total were $91.07 \%$ seedling mortality; on the other hand, the S-1 isolate of S. rolfsii caused $91.33 \%$ seedling mortality. And the seedling mortality rates determine the virulence of the pathogen. Before taking any control strategy they cause a huge loss even before expressing the proper symptoms of the diseases. The results of this study complied with several authors (Ahmed et al., 2019; Pugliese et al., 2008). Many scientists are now working to find out an alternative to chemical pesticides. To control diseases different bio-control agents have been used as alternatives to chemical pesticides. To date, a lot of bio-control agents have been identified. But Trichoderma spp. has a specific specialization in controlling soil borne pathogens; exclusively $R$. solani and S. rolfsii. They inhibit the growth of these 2 pathogens either through mycoparasitism or through direct competition for food, space etc. Some authors also suggested that they have the capability of antibiosis or may induce a response of defense in plants against the soil-borne microbes (Patkowska et al., 2020). Along with disease control, Trichoderma spp. also contributes to plant growth and yield contributing characteristics (Sánchez-Montesinos et al., 2020). Different cultural and chemical methods have been applied up to now for controlling $R$. solani, S. rolfsii, and other soil-borne microbes but none of the tactics was fruitful in controlling them. Rather excessive and indiscriminate use of these chemicals pollutes the environment as well as may affect human health also. In this aspect, Trichoderma spp. has a great impact in controlling the fungi which form resting spore-like sclerotia including $F$. oxysporum, $R$. solani and S. rolfsii (Khalil, 2021; Abbas et al., 2017; Islam et al., 2005). They control pathogens in an eco-friendly manner. In our study, the in vitro screening revealed that $T$. harzianum showed significant inhibition of mycelium growth of isolates of $R$. solani and S. rolfsii which was found to be the most virulent ones, but there were range of antagonism found by different isolates against the test fungi. The genes of antagonism of the isolates of $T$. harzianum or the metabolites which are regarded as the virulence factor or the degree of virulence may be responsible for the variation of their antagonistic behavior (Shanmugam et al., 2008, Kumar et al., 2011, Malmierca et al., 2015). Till date $T$. harzianum isolates have been used against $R$. solani and S. rolfsii by dual plate culture technique by the researchers throughout the world, due to their capability in controlling them (Ali et al., 2017; Bell et al., 1982; Woo et al., 2014). The result of the present study of the application of $T$. harzianum fortified compost in increasing the growth promotion components as well as in increasing total yield supports the increased yield of vegetable crops reported by other investigators who applied $T$. harzianum mixed with compost (Olabiyi et al., 2013; Uddin et al., 2015; Woo et al., 2014). In the present study, enhancement of yield of carrot was observed after the application of Trichoderma fortified compost. This enhancement may be due to the fertilizer like effect of Trichoderma on plant growth as well as their antagonistic effect on pathogens which decreased disease incidence (El-Tantawy, 2009). So it is clear that Trichoderma fortified compost have a direct effect on plant growth and their usage in disease control ensure sustainable management of Rhizoctonia crown rot and canker, and southern blight of carrot disease. Bio management method applied in the present study not only suppress plant disease but also have an impact on plant growth promotion.

\section{CONCLUSION}

Rhizoctonia crown rot and canker, and southern blight of carrot can be effectively controlled by the application of Trichoderma fortified compost. The application of Trichoderma fortified compost more efficiently the dose of $400 \mathrm{~g}$ wheat grain colonized Trichoderma fortified compost increased the germination percentage, controlled pre-emergence and post-emergence seedling mortality and ultimately total seedling mortality, decreased disease incidence and severity over all other treatments. And their application also enhanced the growth of the plant as well as increased the yield of carrots significantly. So this doze can be further recommended for controlling Rhizoctonia crown rot and canker, and southern blight of carrot diseases as well as for promoting yield of carrot.

Funding: University Grant Commission and Ministry of Science and Technology, Bangladesh.

Conflict of Interest: The authors declare no conflict of interest.

\section{REFERENCES}

Ali, A. A., Abd El-Kader, A. E., \& Ghoneem, K. M. (2017). Two Trichoderma species and Bacillus subtilis as biocontrol agents against Rhizoctonia disease and their influence on potato productivity. Egyptian Journal of Agricultural Research, 95(2), 527-541.

Abbas, A., Jiang, D., \& Fu, Y. (2017). Trichoderma spp. as antagonist of Rhizoctonia solani. Journal of Plant Pathology and Microbiology, 8(3).

Ahmed, M. U., Bhuiyan, M. K. A., Hossain, M. M., Rubayet, M. T. \& Khaliq, Q. A. (2019). Efficacy of chitosan and bio-agent in controlling southern blight disease of carrot caused by Sclerotium rolfsii and improvement the crop production. Research in Agriculture and Veterinary Science, 3(3), 113-125.

Barnett, H. L., \& Hunter, B. B. (1972). Illustrated genera of imperfect fungi, (3rd ed).

Bell, D. K., Wells, H. D., \& Markham, C. R. (1982). In vitro antagonism of Trichoderma species against six fungal plant pathogens. Phytopathology, 72(4), 379-382.

Begum, M. M., Hossain, I., \& Haque, M. S. (1998). Biocontrol of seed borne Fusarium oxysporum with Trichoderma harzianum. Bangladesh Journal of Environment Science, 4, 128-133.

Dhingra, O. D. \& Sinclair, J. B. (1985). Basic Plant Pathology Methods. CRC Press, Inc. Boca Raton, Florida. Pp. 132-163.

El-Tantawy, E. M. (2009). Behavior of tomato plants as affected by spraying with chitosan and aminofort as natural stimulator substances under application of soil organic amendments. Pakistan journal of biological sciences, 12(17), 11641173. 
Ganesan, P., \& Gnanamanickam, S. S. (1987). Biological control of Sclerotium rolfsii Sacc. in peanut by inoculation with Pseudomonas fluorescens. Soil Biology and Biochemistry, 19(1), 35-38.

Grisham, M. P., \& Anderson, N. A. (1983). Pathogenicity and host specificity of Rhizoctonia solani isolated from carrots. Phytopathology, 73(11), 1564-1569.

Islam, M. N., Raihan, M. G., \& Rafiq, Z. A. (2005). In vitro evaluation of Trichoderma, fungicides and plant extracts against Rhizoctonia solani and Sclerotium rolfsii of peanut. International Journal of Sustainable Agricultural Technology, 1(1), 14-23.

James, I. 2008. Effects of compositions on food waste composting. Bioresource Technology, 99(17), 8068-74.

Jenkins, S. F., \& Averre, C. W. (1986). Problems and progress in integrated control of southern blight of vegetables. Plant Disease, 70(7), 614-620.

Khalil, M. E. (2021). Beneficial effects of Trichoderma viride and salicylic acid against Fusarium wilt in tomato. Egyptian Journal of Agricultural Research, 99(1), 26-36.

Kumar, K., Amaresan, N., Bhagat, S., Madhuri, K., Udhayaraj, P., \& Srivastava, R. C. (2011). Genetic and physiological relatedness of antagonistic Trichoderma isolates against soil borne plant pathogenic fungi. Archives of Phytopathology and Plant Protection, 44(14), 1399-1409.

Kuter, G. A., Nelson, E. B., Hoitink, H. A. J., \& Madden, L. V. (1983). Fungal populations in container media amended with composted hardwood bark suppressive and conducive to Rhizoctonia damping-off. Phytopathology, 73(10), 14501456.

Malmierca, M. G., McCormick, S. P., Cardoza, R. E., Alexander, N. J., Monte, E., \& Gutiérrez, S. (2015). Production of trichodiene by Trichoderma harzianum alters the perception of this biocontrol strain by plants and antagonized fungi. Environmental Microbiology, 17(8), 2628-2646.

Nitu, N. J., Masum, M. M. I., Jannat, R., Sultana, S., \& Bhuiyan, M. K. A. (2016). Application of chitosan and Trichoderma against soil-borne pathogens and their effect on yield of tomato (Solanum lycopersicum L.). International Journal of Bio science. 9(1), 10-24.

Olabiyi, T. I., Ojo, O. J., Adisa, J. O., \& Ruocco, M. (2013). Efficacy of Trichoderma harzianum, poultry manure and yeast on the growth and yield of soybean grown on nematode infested soil. Journal of Natural Sciences Research, 3(10), 42-47.

Patkowska, E., Mielniczuk, E., Jamiołkowska, A., Skwaryło-Bednarz, B., \& Błażewicz-Woźniak, M. (2020). The Influence of Trichoderma harzianum Rifai T-22 and other biostimulants on rhizosphere beneficial microorganisms of carrot. Agronomy, 10(11), 1637.

Pugliese, M., Liu, B. P., Gullino, M. L., \& Garibaldi, A. (2008). Selection of antagonists from compost to control soil-borne pathogens. Journal of Plant Diseases and Protection, 115(5), 220-228.

Ramesh Sundar, A., Das, N. D., \& Krishnaveni, D. (1995). In-vitro Antagonism of Trichoderma spp. against two Fungal Pathogens of Castor. Indian Journal of Plant Protection, 23, 152-155.

Samuels, G. J. (1996). Trichoderma: a review of biology and systematics of the genus. Mycological research, 100(8), 923-935.

Sánchez-Montesinos, B., Diánez, F., Moreno-Gavíra, A., Gea, F. J., \& Santos, M. (2020). Role of Trichoderma aggressivum f. europaeum as Plant-Growth Promoter in Horticulture. Agronomy, 10(7), 1004.

Santos, A. D., \& Dhingra, O. D. (1982). Pathogenicity of Trichoderma spp. on the sclerotia of Sclerotinia sclerotiorum. Canadian Journal of Botany, 60(4), 472-475.

Shanmugam, V., \& Sharma, V. (2008). Genetic relatedness of Trichoderma isolates antagonistic against Fusarium oxysporum $\mathrm{f}$. sp. dianthi inflicting carnation wilt. Folia Microbiologica, 53(2), 130-138.

Sivan, A., Elad, Y., \& Chet, I. (1984). Biological control effects of a new isolate of Trichoderma harzianum on Pythium aphanidermatum. Phytopathology, 74(4), 498-501.

Tuite, J. (1969). Plant pathological methods: Fungi and Bacteria Burgess Publication Co., Minneapolis, Minn., USA. 293pp.

Uddin, A. S. M. M. and Hoque, A. K. M.S. (2004). Effect of nutrients on yield of carrot. Pakistan Journal of Biological Science, 7 , 1407-1409.

Uddin, A.F.M. J., Hussain, M. S., Rahman, S. S., Ahmad, H., \& Roni, M. Z. K. (2015). Effect of Trichoderma concentrations on growth and yield of tomato. Bangladesh Research Publication Journal, 11(3), 228-232.

Woo, S. L., Ruocco, M., Vinale, F., Nigro, M., Marra, R., Lombardi, N., Pascale, A., Lanzuise, S., Manganiello, G., \& Lorito, M. (2014). Trichoderma-based products and their widespread use in agriculture. The Open Mycology Journal, 8(1).

Copyright: (C) 2021 by the authors. Licensee EJAR, EKB, Egypt offers immediate open access to its material
because making research accessible freely to the public facilitates more global knowledge exchange. Users
can read, download, copy, distribute, print or share a link to the complete text of the application
under Creative Commons BY-NC-SA 4.0 International License.




\title{
المقاومة الحيوية لعفن التاج واللفحة الجنوبية في الجزر باستخدام السماد المحتوى على التريكودارما
}

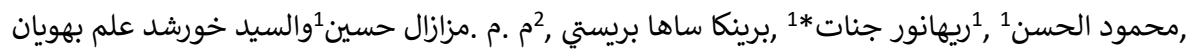

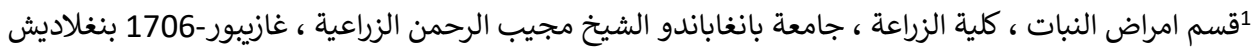

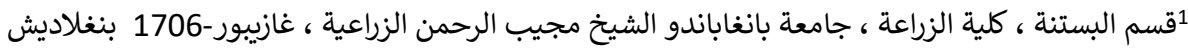

rjannat@bsmrau.edu.bdبريد المؤلف المراسل*

\section{الملخص}

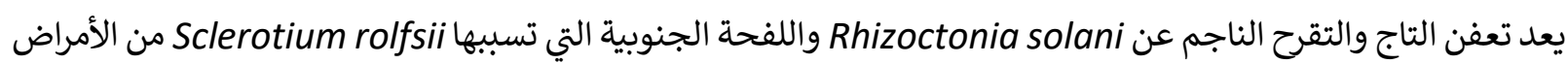

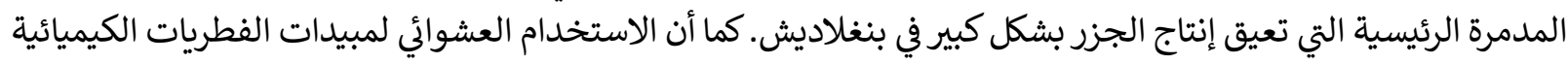

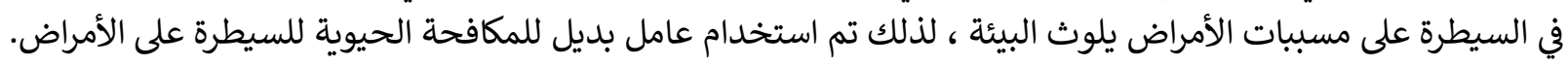

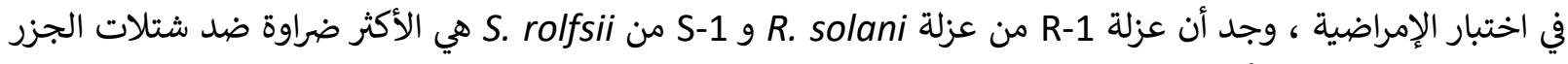

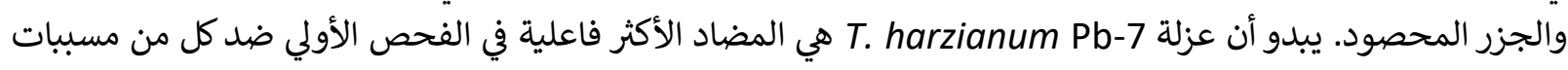

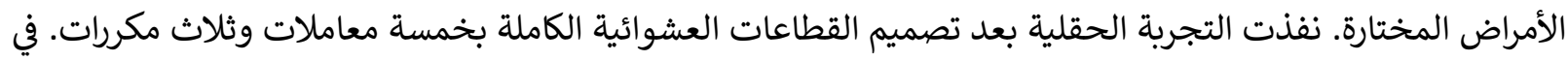

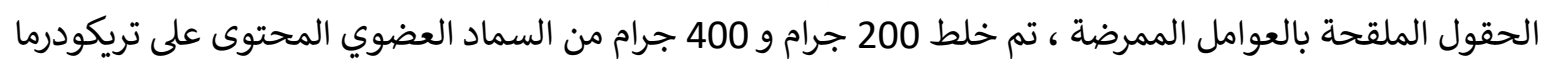

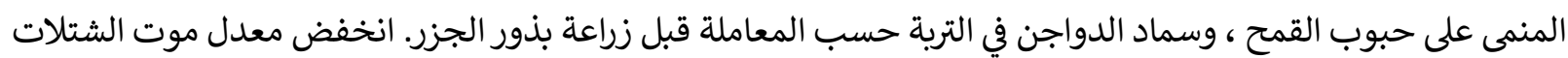

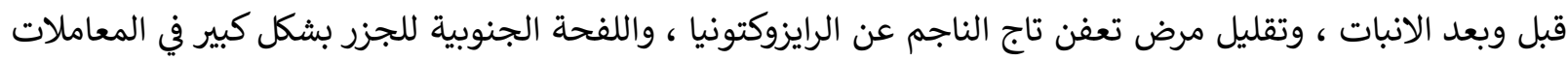

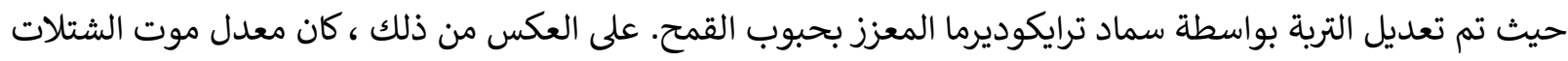

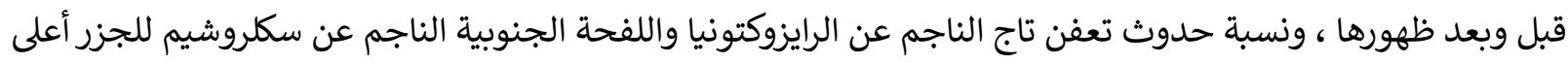

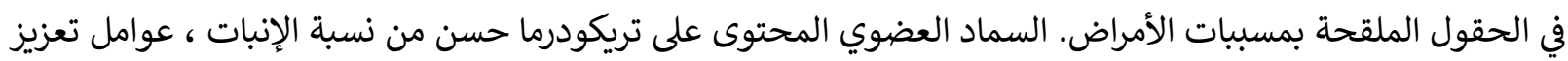

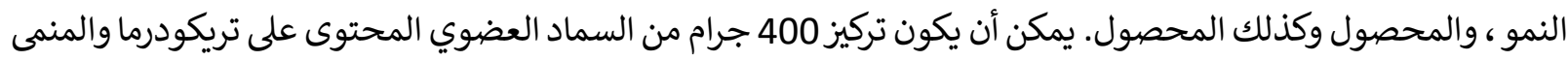

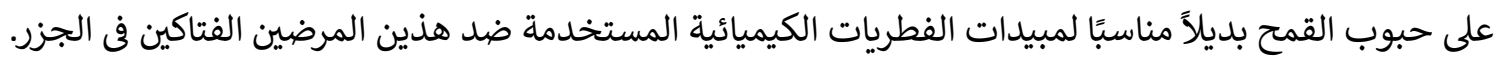

الكلمات المفتاحية: الجزر ، تعفن التاج ، اللفحة الجنوبية ، السماد العضوي المحتوى على تريكودرما 